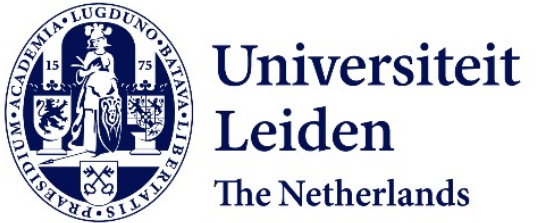

\title{
Muslim saints in the age of neoliberalism
}

Soares, B.F.; Weiss B.

\section{Citation}

Soares, B. F. (2004). Muslim saints in the age of neoliberalism. In Producing African futures: ritual and reproduction in a neoliberal age (pp. 79-105). Leiden: Brill. Retrieved from https://hdl.handle.net/1887/9604

Version: $\quad$ Not Applicable (or Unknown)

License: $\quad$ Leiden University Non-exclusive license

Downloaded from: https://hdl.handle.net/1887/9604

Note: To cite this publication please use the final published version (if applicable). 
Spivak, Gayatri Ghakravorty. 1998. 'Cultural talks in the hot peace: Revisiting the global village.' In Cosmopolitics: Thinking and feeling beyond the nation, edited by Peng Cheah and Bruce Robbins, 329-343. Minneapolis: University of Minnesota Press. Stock, Edward.1899. History of the church missionary society. London: Gilbert and Rivingdon. Stychin, Carl. 2002. 'From integration to civilisation: Reflections on sexual citizenship in a European legal order.' Paper given at Gender, Sexuality and Law II conference, Keele University, June.

Sumaka'i Fink, Amir, and Jacob Press, eds. 1999. Independence Park: The Lioes of gay men in Israel. Stanford, CA: Stanford University Press.

Tylor, Edward Burnett. 1874. Primitive Culture Vol. 1. Boston: Estes and Lauriat.

Watney, Simon. 1990. 'Missionary positions: AIDS, Africa and race.' In Out there: Marginalization and contemporary cultures, edited by Russell Ferguson, Martha Gever, 'Trinh T. Minh-ha, and Cornel West, 89-106. Cambridge, MA: The MIT Press.

\section{MUSLIM SAINTS IN THE AGE OF NEOLIBERALISM}

\section{Benjamin F. Soares}

Approaches to the study of religion and modernity inspired by Weber and some of his interpreters tend to posit that the rationalization accompanying the spread of education, urbanization, and other signs of the modern, necessarily leads to a decline of so-called traditional religious practices (cf. Weber 1978). While anthropologists have long deemed such models to be of doubtful utility in understanding most societies, the persistence of such Weberian approaches-or, at least assumptions -in the anthropological study of Muslim societies is striking. Indeed, there is a considerable body of anthropological literature that points to the waning influence of Muslim saints, their practices, and organizational structures (the Sufi orders) in different Muslim societies. The general argument is that saints and their 'magical' practices become less socially relevant with increased education, urbanization, and the rise of a middle class, and the saints become confined to the 'popular' or 'traditional' elements or socially marginal in Muslim societies (e.g., Crapanzano 1973; Eickelman 1976; Gilsenan 1973, 1982; cf. Ewing 1983; Hoffman 1995), and are eventually replaced by 'orthodox' scripturalist Islam (Geertz 1968, Lambek 1993). Such approaches are perhaps best exemplified in the work of Gellner, who asserts that with "the coming of modernity" and the arrival of the 'modern' state those quintessentially traditional religious figures, Muslim saints, "are seen to retain some of their [inherited] perks but to perform little or no social function" (Gellner 1981, 56-7; cf Asad 1986, Zubaida 1995). According to Gellner, the religious authority of saints will necessarily decline in the face of "reformist" Muslims, those more 'modern,' sober, textually oriented Muslims-effectively Weberian puritans - who question the legitimacy of saints and their 'traditional' practices (Gellner 1981: passim; see also Gellner 1992, 1994).

Such assumptions and narratives are even apparent in some of the most recent social science literature about Muslim societies, as, for example, in the considcrable attention to so-called Islamism or political Islam. ${ }^{1}$ However, other scholars, pace Gellner, have pointed

\footnotetext{
${ }^{1}$ For example, in Muslim Politics, Eickelman and Piscatori (1996, see also Eickelman
} 
to the continuing importance, even reverence of such 'traditional' figures as Muslim saints in certain Muslim societies. This is the case, most notably in parts of Africa, and Senegal in particular, where various studies have focused on the Mourides, a Sufi order, and its founding Muslim saint, Amadou Bamba, and his followers and successors (cf. Copans 1988; Cruise O'Brien 1971, 1975; Coulon 1981, Seesemann 1993). While it is arguably misleading to suggest that the experience of the Mourides and Muslim saints in Senegal is in any way typical of postcolonial Africa, ${ }^{2}$ Muslim saints are key actors in certain places in postcolonial Africa, as they are in Mali. ${ }^{3}$ Nearly two decades of neoliberal reforms and the implementation of structural adjustment programs have been accompanied by sharp economic decline in Mali. Most Malians-salaried and unsalaried-have difficulty making a living, whether in agriculture, trade, or the civil service. While social reproduction has become both more difficult and elusive for most Malians, many elite and nonelite Muslims stand firm in their attachment to particular Muslim saints who seem to have become even more important in this era of fantastic wealth alongside deprivation-a situation in which narratives of progressive rationalization are simply not relevant.

Drawing on research in two different and sometimes competing Islamic religious centers and among three lineages of Islamic religious specialists in postcolonial Mali, I trace transformations in the nature of the religious authority that have accompanied the period of neoliberal reforms. I examine some of the ways in which the

1998) attempt to assess the complexity of changes occurring within various contemporary Muslim societies but, in doing so, fail to deal adequately with the continuing importance of such 'traditional' figures as Muslim saints and their 'esoteric' (or 'occult') practices in certain societies. See Comaroff and Comaroff 1999 for a discussion of the importance of the occult.

${ }^{2}$ For a critique of the overemphasis on the Mourides or 'Mouridocentrism' in the study of Islam in Africa, see Triaud 1986. A notable exception to such the study of Islam in Africa, see

3 The importance of saints in postcolonial sub-Saharan African and particularly ${ }^{3}$ The importance of saints in postcolonial sub-Saharan African and particularly
in former French colonies clearly relates to the history of colonial rule and French colonial policies towards Muslims - what was called 'la politzque musulmane.' During the colonial period, the French colonial administration generally sought the 'loyalty' of 'marabouts'--Mushm religious leaders, saintly or otherwise - to whom ordnary people were assumed to owe allegiance French colonial policy toward Islam and Muslims might be summed up as the attempt of the French to elevate a Muslin establishment, including some saints who have played important roles in the postcolonial period. On such colonies' policies and their implications, see Harrison 1988 Launay and Soares 1999, Robinson and Triaud 1997, and Soares 1997b, 2000 world of commodities has come to permeate the largely ritualized 'visits' with or 'pilgrimages' to exceptional Muslim religious leaders considered saints. I argue that certain processes of commodificationthe exchange of blessings and prayers for commodities, the proliferation of personal and impersonal Islamic religious commodities-have intensified around saints in the neoliberal era. Such processes of commodification have facilitated the personalization of religious authority in certain provincial Muslim saints, to whom many have turned for succor in these times of political and economic uncertainty. These living Muslim saints are exemplars for ordinary people though clearly not the puritans or ascetic world-renouncers that Weberian models would lead one to expect (e.g., Dumont 1980, Tambiah 1984, cf. Sahlins 1992). Through their great wealth, very large families, and large entourages, certain Muslim saints exhibit the capacity for successful social reproduction, which is precisely what has become much more difficult for the vast majority, who face an increasingly precarious existence in the era of neoliberal reforms, declining real wages, cutbacks in public services and education, and recurring political crises. I argue that such saints have become more privatized religious figures-effectively free-floating sanctifiers - in a religious economy that has come to be more like a market. Not only have these Muslim saints been able to outlast secular political regimes, but they also seem to have overcome some of the uncertainties of the market and even appear to offer ordinary people the means of doing so.

\section{Saints and Superstars}

I want to begin with a discussion of Muslim saints in Mali. Although the term saint is borrowed from Christianity, it is preferable to some of the other possible options- such as marabout in French or shaykh in Arabic-which are too vague for the exceptional Muslim religious figures of Mali. By saint, I am referring to the term wali in Arabic, which is actually a loan word in many languages spoken in West Africa. ${ }^{4}$ If there are different ways of being a Muslim saint and

${ }^{4}$ The term is used in all the major languages spoken in the region of my research, including Bamanakan/Bambara, Hassaniyya, Jakhanke, Pulaar/Fulfulde, and Soninke. It is interesting to note that some non-Muslim Bambara in the regon use the same It is interesting to note that sol nelous downplay the influence of Islam on non-Muslims' religious practices notwithstanding- 
various 'modern' trajectories of Muslim sainthood in contemporary West Africa, the Muslim saints I consider here are all well-known religious leaders, who, with one exception, are still living. In Mali, only the most exceptional Muslim religious leaders are considered saints. A whole host of possibly intersecting circumstances - attracting many followers; developing a reputation for learning, piety, and generosity; or having prodigious powers, such as mystical insightmay lead some people to consider a religious leader exceptional. Although much of the scholarly literature dealing with Muslim societies discusses such phenomena by way of the concept of baraka, usually glossed as blessing, 'grace,' or as some kind of unproblematic Weberian conception of charisma, I want to suggest that these phenomena are considerably more complex. ${ }^{6}$ In large parts of West Africa, some people are thought to have special 'power,' with power conceived as force in its spritual and material senses, suggesting authority in Weberian formulations (cf. Weber 1978, Turner 1974).

Power here is meant to indicate God's favor, for which there is no single term but is instead a whole host of related notions in the region's vernaculars, such as 'gifts of God,' as well as baraka, hurmo (Arabic, sanctity), and $n^{\prime} m a$ (Ar., prosperity), to name only a few words of Arabic origin in the region's vernaculars that people frequently invoke when they talk about important Muslim religious leaders. There is a sense that power emanates from God who bestows his favor on whomever he wants (cf. Denny 1988). Broadly conceived, God's favor is indexed by all that people might want: wealth, good health, power, progeny, good fortune, social prestige, and so forth

The truly exceptional-even more so than those with 'power'are thought to be saints. ' Saints are usually men, though in some cases they can be women, and saints may be living or deceased; the latter is perhaps the most important difference between Muslim and Christian saints. People presume that saints are actually closer than ordinary Muslims to God, as well as to the Prophet Muhammad-at least in a metaphorical sense. Malian Muslims talk about saints as leading exemplary lives in the sense that they follow very closely

See Ewing 1983 and Werbner and Basu 1998 for a discussion of Muslım saints and sainthood in South Asta

Cf Geertz 1968, Gulsenan 1973, Eickelman 1976, and Cruse O'Brien and Coulon 1988, to name only some of the most influentual studies of Muslim saints For a recent example, sce Hammoudi 1997

Much of the scholarly hterature refers to these people as saints and points to their chansma-like qualitues ( $\mathrm{g}$, Gellner 1969, Cruse O'Brien and Coulon 1988) the life of the Prophet Muhammad, who was known as 'the Perfect Man' (Ar., al-insan al-kaml). This notion that Muhammad was the perfect man has been developed in the scholarly literature of Sufism, the mystical tradition in Islam; it is widely understood by Muslims from broad sectors of the society in this part of West Africa. ${ }^{8}$ By association with the Prophet Muhammad and his exemplary life, saints embody a certain kind of morality. Like the Prophet Muhammad, they are known for their piety and devotion to God and their other positively valued qualities, which are thought to surpass that of ordinary Muslims. Malian Muslims, like many Muslims elsewhere, point out that it is God who confers sainthood upon whom he chooses. In this context, one never declares oneself a saint. This contrasts, for example, with the celebrated thirteenth-century Sufi, Ibn 'Arabi (Chodkiewicz 1986), or more directly relevant for the context of my research, Ahmad alTijani, the founder of the Tijaniyya, perhaps the most important Sufi order in West Africa (Abun-Nasr 1965), both of whom are reported to have proclaimed themselves to be living saints.

Athough one may be a saint without one's or others' awareness of it, there are certain reported signs of sainthood, particularly an association with wondrous things -karamat in Arabic and kabako in Bamanakan/Bambara, Mali's most important lingua franca. One of the most frequently discussed of such wonders in Mali is the ability to predict the future. Moreover, it is widely reported in Mali and much further afield that God will answer the supplicatory or petitionary prayers (Ar., du'a) of a saint or at least it is more likely that God will answer such prayers. This relates to the idea that saints have special access to God and his favor. For this reason, many seek out saints to ask them to intercede on their behalf with God. In short, such saints "speak for men to God" (see Beidelman 1971). At the same time, many fear saints. Many Malians told me that to be against a saint was basically to be against God. ${ }^{9}$

${ }^{8}$ On the subject of the perfect man, see chapter 2 of Nicholson 1921 See Soares and Hunwick 1996 for a discussion of a poem from West Africa that prases a particular saint-the father of one of the saints discussed here - in terms like that of the perfect man See also Werbner 1998 for a consideration of this notion among Sutis in Pakistan and Britain and the exemplary hife of saints

9 Such a notion almost certainly comes from the statements and practices attribSuch a notion almost certanly comes from the statements and practices attributed to the Prophet Muhammad (hadtths on 'traditions') Malian Muslim scholars earn such haduths through the study of texts in Arabic Many laypcrsons also learn also part of oral discourse in this region 
In Malı, people can learn about contemporary Muslim saints through eyewitness accounts and oral narratives about the wonders associated with them, but perhaps as often through radio, television, and popular culture, more generally. Malians can view coverage of the annual visits with saints on national television in programs that usually feature images of the large crowds in attendance or listen to coverage of such annual events on national radio. They can also listen to audiocassette recordings of grots and other such 'traditionalists' who laud the virtues of a particular saint or hear songs in praise of various saints and their illustrious ancestors on the radio. ${ }^{10}$ In one song that has received a lot of attention in Mali, a Malian recording artist, Ina Baba Coulibaly, sings about her own 'pilgrimage' to the town where a Malian saint lives and the blessings she anticipates. ${ }^{11}$ The most prominent saints in Mali have celebrity status. We might even call them the superstars among the contemporary Muslim religious leaders of Mali.

Beginning in the 1970s, the decade following independence from French colonial rule and after the overthrow of Mali's first postcolonial socialist regime (generally considered hostile to religion), several lineages with claims to Islamic religious authority initiated annual large-scale 'visits' - the term used derives from the Arabic ziyarawith celebrated saints in provincial towns quite a distance from Bamako, the capital and largest city, as well as from other important centers of economic activity in Mali. Located on the edge of the desert, the towns are backwaters whose roles in the economy declned along with trans-Saharan trade, the development of colomal urban centers, and recurrent periods of drought. Although there have been high rates of migration from these towns to areas of greater economic activity, the economic changes associated with neoliberalism - the opening up of local markets, the flood of imports, and the decline of the cconomy-have meant that even more people are having difficulties making ends meet. For this reason, migration increased to other places in Mali, to more prosperous countries such as Côte d'Ivoire or to Central Africa, not to mention long-term

10 Some of these recordings are commercially produced and avallable for sale in the market See McLaughin 1997 for a discussion of Islam and popular music in neighboring Senegal

11 Ina Baba Coulbaly, Allah hollame [Fulfulde, "God show me "] (Camara Productions, Paris, nd, CK7 03I) migration to France and much farther afield. Be this as it may, the towns in which the saints live are known in the urban imaginary, not only as important centers of Islamic learning--both past and present-but also as places where the inhabitants are thought to be more pious Muslims and the actual towns are thought to be blessed.

The saints and their lineages are what we might call saintly lineages, following anthropologists, such as Gellner (1969) and Geertz (1968), who both worked in North Africa. These saintly lineages descend from key precolonial and early colonial Muslim religious figures with reputations for scholarship, piety, association with wondrous things, the propagation of Islam in the region, and, in one case, persecution under French colonial rule. ${ }^{12}$ While members of one of the saintly lineages claim descent from the Prophet Muhammad, the other two lineages - whose saintly reputations are no less impeccable - do not. Each of the saintly lineages is also associated with one of the two principal Sufi orders present here - the Qadiriyya or the Tijaniyya - and members of the lineages hold high-ranking positions within these Sufi orders. Since the late 1980s, with the advent of the era of neoliberalism, the saints seem to have acquired fantastic wealth. They live in great comfort in newly constructed imposing homes, surrounded by their families (invariably comprising several wives and numerous children - upwards of fifty each in two of the cases), many followers, servants, and retainers.

There are representatives of each saintly lineage living in the capital, not to mention in other towns and cities in Mali and in neighboring countries. These representatives coordinate the trips of individuals and delegations - both men and women-to the respective provincial towns for the annual visits, which have become highly organized affairs involving thousands of people. ${ }^{13}$ Many of these people are urban dwellers, often migrants, involved with modern economic activities, who usually travel in groups to the towns where they spend a few days, a week, or longer. During the visits, people gather for performance of the ritual daily prayers, or salatt. They listen to poetry in honor of the Prophet Muhammad and of the respective saint, and his ancestor(s). In the afternoons and evenings, people

\footnotetext{
12 I have written elsewhere about the histories of the santly lineages considered here See Soares 1996a, 1997a, 1997b

13 Two of the 'vists' follow the Islamic lunar calendar and are held on or shortly after the mawhl, the celebration of the Prophet Muhammad's birth The third annual
} visit is held around harvesttime in December or January 
also listen to other, usually more junior, religious leaders who give sermons-often in the vernaculars - about Islam and the way to conduct oneself as a proper Muslim. ${ }^{14}$ Those who are members of the Sufi order to which the saint belongs also meet to recite collectively the special litany of prayers (Ar., wird) of that particular Sufi order. Visitors also eat meals with groups of other visitors and, usually, at least once, all together. ${ }^{15}$

\section{Gifts and Commodities}

One of the central features of the relationship between saintly lineages and ordinary Muslims in Mali is the giving of gifts. Muslims in West Africa have long brought gifts to religious leaders, usually seeking blessings from them or for their intercession with God. I want to relate such gifts and gift giving to regionally salient conceptions of Islam and what is thought to be the proper comportment of Muslims before considering changes in the era of neoliberalism. In Islam, Muslims are not only encouraged but also commanded to give to others. Along with prayer, giving to others is one of the main virtues repeatedly stressed in the Qur'an, the sacred text for Muslims. Indeed, one of the so-called five pillars of Islam is zakat, or the alms expected from all Muslims. Such alms are obligatory, and many, if not all, Malian Muslims would state this is the case. In the past, before French colonial rule, certain Muslim religious leaders and rulers in this part of West Africa collected what they considered zakat. Under colonial rule, the French suppressed the collection of zakat and imposed a system of taxation not based on Islamic jurisprudence that has survived into the postcolonial period. Today, what many Muslims in Mali, including saints, give annually to the poor and needy, and what they also give to the poor at the end of Ramadan (the yearly month of fasting from dawn to dusk) is called zakat. Many people elsewhere in the Muslim world use the same term.

One finds another notion of alms, sadaqa, that is rather different

${ }^{14}$ None of the saints discussed here makes public pronouncements or seimons ( $\mathrm{Ar}$, wa'az) that circulate on audrocassettes or in written form, as is the case for other Muslims elsewhere in Malı and in many places in the contemporary Muslim world On the history of Muslim preachers and public sermons in Mali, see Soares nd 2 ${ }_{15}$ Space limitations prevent me from discussing the considerable economs of such a plgrimage economy on the two towns. from zakat but equally, if not more, important in Muslim West Africa. In general, what one gives willingly and informally to others in one's daily life or what one gives, sometimes even sacrifices, following the recommendations of a Muslim religious leader is considered sadaqa. ${ }^{16}$ It is this second notion of alms or charity that is undoubtedly more widespread in this part of West Africa. According to the Qur'an and other Islamic texts, such as hadiths, such alms are usually for the poor and the needy (see Ali 1984, ix, 60). Therefore, the gifts that Muslim religious leaders receive are not considered alms. This clearly relates to the idea that descendants of the Prophet Muhammadsharifs (Arabic)--never keep alms for themselves. One finds this in local discourse and practice, as well as in statements attributed to the Prophet Muhammad (sce El Bokhari 1964, 138). In principle, those lineages claiming descent from the Prophet Muhammad, and, by extension, all religious leaders of elevated status in this part of West Africa, never accept gifts designated as sadaqa for their own consumption (that is, at least, in theory). In practice, some people do give alms to elevated religious leaders for distribution to the poor on their bchalf.

In any case, the gifts that the most esteemed Muslim religious leaders in Mali ordinarily receive are called hadaya in the region's vernaculars - Pulaar, Soninke, Bamanakan, Hassaniyya, and in other languages spoken in the vicinity. This word, hadaya, comes from the Arabic word (hadiya; pl., hadaya) meaning 'gift' or 'present.' If in some places in the Arabic-speaking world, such as nineteenth-century Egypt, the word simply means 'gift,' the term is used exclusively for gifts in this part of West Africa given to descendants of the Prophet Muhammad and to descendants of al-Hajj Umar Tall, the leader of a nineteenthcentury Islamic state in this region, as well as others of similar stature. In other words, hadaya are gifts given to Muslim religious leaders of very high status, like the three main saintly lineages I have studied. Although some gifts offered to the Sultan in Morocco have been so designated (Colin 1971, Dannerlein 2001), the longer history of these practices of gift giving in West Africa and their possible relationship to practices in North Africa are not at all clear (cf. Hamès 1979). It is striking, however, that hadîya-gift giving to religious leadersdoes not figure as a category discussed in any way in the standard

${ }^{16}$ For a discussion of such 'sacrifice' in a West African context, see Launay 1992, cf Bowen 1992 
Islamic legal texts used in this region. ${ }^{17}$ All of the saints have reputations for redistributing a portion of what they receive as alms to the poor and to members of their rather large entourages.

In giving gifts to others and quite often preferably to religious leaders of elevated status, it is clear that people are doing more than simply following Islamic legal texts or mechanically enacting rules for alms or gift giving. In this context, one can say that in giving gifts to others, people are often following religious commands. As many of my informants noted, in giving gifts they wished to obtain baraji, which means merit or divine recompense in several vernacular languages in Mali. Although there was no consensus among my informants about the origins of the word baraji, ${ }^{18}$ some Muslim scholars explained that the term corresponds to the notion of merit (Ar., thawâab) one finds in Islamic religious texts, while other scholars suggested other terms with similar meanings (for example, Ar., 'ajr). ${ }^{19}$ There was, however, agreement among my informants that baraji clearly has a sense of merit, which, they explained, is the reward from God for one's actions. One receives such a reward in this world-wealth, good health, progeny, and so forth-or in the hereafter, that is, either access to heaven and eternal life or hell. There is a prevailing notion that one receives such merit for alms-obligatory alms (zakat), voluntary alms (sadaqa), gifts, and generosity more generally. Those who gave to others, including gifts to religious leaders, explicitly stated that in doing so they hoped to receive such merit. Because saints are thought to be close to God, one honors God through giving gifts to saints, thereby possibly obtaining merit and, ultimately, God's favor. Uncertainty is, however, inevitable. One never knows whether or how exactly one will benefit from such merit in this world or the next. In any case, I want to emphasize that it is this notion of baraji that is more important here than, say, baraka, which many anthropologists have highlighted, perhaps even overemphasized. ${ }^{20}$

${ }^{17}$ See Ruxton 1916 and al-Qayrawani 1975, which are two standard texts of the Maliki school of jurisprudence used in West Africa.

${ }_{18}$ Some informants pointed out that the word did not appear to be of Arabic origin. As evidence, one person noted that in Fulfulde/Pulaar the word did not belong to the same noun class usually reserved for words of foreign orign, including many words from Arabic

ing many words from Arabic
19 It is interesting to note that this word sometumes has the meaning of gift or It is interesting to note that this
present (see Kazmirski 1860, 1.13)

${ }^{20}$ See the references in note 6 . I would not, however, go so far as Bourdieu who writes about "the almost emply notzon of baraka" [emphasis in original] (1977, 228, n. 89 )
In exchange for gifts, Muslim religious leaders, including saints, give blessings or petitionary prayers - in the local vernaculars duwaw, another loan word from Arabic - exactly as the Prophet Muhammad is reported to have done when he received gifts (see Wensinck 1927, 88). As I have already noted, people say that God is more likely to answer the prayers of a saint because saints have special access to God and his favor. For this reason, individuals often seek out the blessings of a saint or attempt to cultivate a relationship with a saint and ask him to intercede with God in the hope of having personal concerns addressed. Concerns of this nature might include the pursuit of wealth or prestige, or simply the avoidance of misfortune. People report that saints are generally solicited less than they were in the past for everyday somatic ailments. Frequently, when medicine fails - during debilitating illnesses or chronic health problems, such as infertility or what might be called mental illness-people approach Muslim saints for intervention.

Because people consider giving gifts to saints morally correct, potentially meritorious, even obligatory, visiting a saint without bringing a gift is almost inconceivable. If one usually gives according to one's means (but compare below), people also note that a gift should correspond to the stature of both the person giving and the person receiving. ${ }^{21}$ One saint told me that he accepts all gifts-regardless of size or value - that people offer to him. On one occasion, while I was talking with one of the saints, a follower and companion of the saint - a very poor man - approached and handed him a coin roughly equivalent to a few pennies. Just a couple of days before, one of the same saint's wealthy followers living in the capital had given the saint a brand new imported all-terrain vehicle to facilitate his travels.

For many people, the high point of an annual visit is the time during which they deliver gifts to a saint. In rather formally structured rituals, saints receive visitors-both men and women. I have seen ordinary followers lining up by the hundreds, waiting as individuals or in groups to hand over their gifts-livestock, agricultural products, consumer goods, envelopes filled with cash - to a member of the saint's entourage as the saint stood close by. If one is lucky, one might be able to shake the saint's hand at this time. Or the saint might place his hand on one's shoulder or head or touch one's prayer beads. These are all ways of blessing or transmitting charisma,

${ }^{21}$ Eickelman $(1976,178)$ found similar practices in Morocco 
to use the language of Weber. Such contact, however fleeting, is greatly anticipated and eagerly sought. I have seen people trembling with anticipation as they waited to hand over their gifts and possibly be touched by the saint. Given the number of people involved in the annual visits, these ritualized exchanges would be the closest direct contact that most ordinary people visiting one of the towns would have with a saint.

Indeed, most ordinary people are kept socially and spatially apart from the saints. Access to the saints is so consistently regulated that it cannot be emphasized enough. I encountered many people followers, those with some sort of problem, or simply the curiouswho explained how they had made the journey to one of the provincial towns at times other than during the annual visits, but they had been unable to see the saint. ${ }^{22}$ Such access to the saints is even restricted for those who live in the towns. At the weekly Friday communal prayers when the saints usually pray with their respective communities, social and spatial distance is sharply marked. For example, one saint usually prays inside a building at his zawiya (Ar., Sufi center), unseen by most others who pray together in the more public space of the zawiya. Before and after prayer, this saint moves in and out of the more public space. As he does so, women seated together in an area behind the men, as in a mosque, watch the saint, and some of the women ululate when he is in their view. Usually, the saint and his retainers allow men and boys to approach. Women and girls are not permitted in this central space of the zawizy during prayer times and thus watch from afar. The saint stands for a few minutes inside the portal of the building that houses his private space for prayer. Gathering on the verandah before the saint, men and boys, including many of lower status-the unemployed, the infirm, and the destitute approach to touch the saint's outstretched hand, which they sometimes also kiss, out of respect and/or in order to be blessed (cf. Messick 1993, Gilsenan 1982). Others lower their heads so that the saint might touch them. Throughout, several retain-

$$
(-\cdots
$$

${ }_{22}$ Although space limitations prevent me from discussing more fully the issuc of access to the saints, I do want to note that the saints' retainers, who are often privleged members of their entourages, act as intermediaries with almost all of those seeking access to them. I am also unable to discuss the different ways of gainm access such as mobilizing kin or client tics with the saints I have discused some of these issues in Soares n.d. 1 . ers engage in crowd control. They prevent people from lingering too long or getting too close to the saint.

While it is clear that the regulation of access to such saints is important in no small part because of the sheer number of followers involved, the limited visibility of such religious leaders enhances their sanctity and power (Graeber 1996, cf. Eickelman 1976). A visitor or even someone living in one of the provincial towns might catch a glimpse of the saint during communal prayers, possibly hear a message delivered on his behalf over a loudspeaker, or even kiss his hand after communal prayers. But a private audience with a saint - no matter how much desired-is nearly unattainable for most ordinary people, who, thus, are usually unable to communicate their own this- or other-worldly concerns directly to a saint. We might say, in neo-Durkheimian fashion, that such people (residents or visitors to the towns) with often quite different backgrounds forge a collective religious identity, expressing this identity as followers of one of the saints. ${ }^{23}$ Such people receive blessings and/or potential merit in exchange for their gifts.

Although for centuries certain Muslim saints in West Africa have been associated with commodities, such as the gold, salt, and slaves they accumulated and exchanged during the trans-Saharan trade, and, more recently, with major cash crops, such as groundnuts in neighboring Senegal, recent processes of commodification have complicated matters. ${ }^{24}$ In recent years, visits with saints have increasingly come to resemble a marketplace in that contact with them has come to be mediated on an unprecedented scale by both commodities and money. In what are clearly new ways of indirect access to saints, people are able to purchase desirable Islamic religious commodities (cf. Starrett 1995). Most notably, one saint's image was printed on bolts of fabric in exactly the same way the Pope's image has been printed on fabric in Africa. The fabric with the saint's image almost immediately became a best-seller among those who were fond of the

${ }^{23}$ As I have argued elsewhere (1996b), Turner's notion of 'communitas' (1973) is not quite applicable here.

${ }_{24}$ On the history of this region of West Africa durng the trans-Saharan trade, see Wills 1976 . For the involvcment of samts in the cconomy of Senegal, see the see Wills 1976. For the mvolvcment of sants in the cconomy of Senegal, see the important studies of the Mourldes by Cruise O'Brien (1971, 1975) and Copan omy in Senegal remains to be written, see Perry 1998 . 
saint. Depending on one's means, one can also purchase a saint's photo that might easily cost more than the average daily wage. Or, since the late 1980 s, one can also usually purchase a videocassette recording of the proceedings of the annual visit that features closeups of the saint, members of his inner circle and sometimes even the anthropologist. Needless to say, such videos-produced in towns where public electricity is unavailable -are many more times expensive than a saint's photo. In some cases, saints have authorized certain individuals to make what amount to official video recordings of the annual visits and sometimes to take their portraits. Guaranteed such privileges, some of these people--entrepreneurs so to speakhave profited handsomely from the sale and distribution of these religious commodities. ${ }^{25}$ Given how eager people are to add a saint's photo to their collections, many recognize the potential profit to be had from the reproduction and sale of saints' photos. At the annual visits, I have watched as crowds have quickly gathered around those announcing the sale of official and unofficial photos.

All of these religious commodities - photos, videos, printed fabric - can be widely diffused ${ }^{26}$ Indeed, they circulate with the visitors who pass them on through trade and exchange with others at home and among migrant communities elsewhere in Africa and beyond who might not be able to travel to the provincial towns for the annual visits. I have found such religious commodities - photos of saints prominently displayed in living rooms and videos of the annual visits - in the homes of Malian migrants living in France. More than one Malian in France told me he recognized me from viewing the official videotaped recordings of those annual visits I attended (and during which I was invariably videotaped). And because of my association with and relatively easy access to the saints, Malians repeatedly ask me to give them or even to sell them photos of the saints they assume I must have.

Such religious commodities have certainly helped to spread the reputations of the saints and their 'fame' (Munn 1986), but also their presumed arc of power. For many, these religious commodities unambiguously index the saint's influence and sanctity. These religious commodities have undoubtedly helped to make the handful of saints

20 See Tambrah 1984 on amulets.

${ }_{26}$ The fabric seems to have been rarely worn, instead becoming a collector's item that women store away with the intention of passing on to female kin. superstars, not least because most are aware that it is not just anyone whose image can be commercially viable. Many seem truly awed by the video and photographic images of the enormous crowds gathered under the leadership of the respective saints during the annual visits. Some have told me that they have made plans to attend or have actually attended the annual visits after the lasting impression such images have made on them. This has not, however, meant the unproblematic spread of the saints' influence along with the flow of such religious commodities. It is interesting to note that the fabric with one of the saint's images and, by extension, that particular saint became the subject of critique by certain Muslims, perhaps a minority, who have been opposed to such representational art. Such people-we might call them 'reformist' Muslims-see such images as evidence that the saint, or, at the very least, some of his followers are guilty of idolatry or 'association' (Ar., shirk), that is, treating things other than God as a deity; in short, this is un-Islamic behavior. ${ }^{27}$ This is just one feature of a larger Muslim 'reformist' discourse that contests the legitimacy of all supposed living Muslim saints, their alleged powers of intercession, and, by extension, giving gifts to them.

Such criticisms are very serious indeed and may partly explain why some saints have taken steps to restrict the commercialization of their images or what they see as excessive profiteering in the sale of such images. Clearly, the saints do not savor the idea of just anyone profiting financially from the sale of their images. On more than one occasion, I have seen a saint stop someone from taking his photo or videotaping him. Once I watched as a saint instructed a member of his entourage to prevent a young man from videotaping him and the activities at the annual visit. I later learned that the young man was the son of a wealthy migrant without any particular attachment or relationship to the saint, and this man was merely seeking to exploit the commercial possibilities of videotaping the saint. While the saints have sometimes reacted angrily to the unauthorized commercialization of their images or excessive profiteering, they have not been able to control the proliferation and circulation of these commodities, even if they wished.

${ }^{27}$ On so-called reformist Mushms and their discourses in Mahl, see Brenner 1993, Amselle 1985, and Soares 1997a, 1997b. For Niger, see Masquelier 1999. 
saint. Depending on one's means, one can also purchase a saint's photo that might easily cost more than the average daily wage. Or, since the late $1980 \mathrm{~s}$, one can also usually purchase a videocassette recording of the proceedings of the annual visit that features closeups of the saint, members of his inner circle and sometimes even the anthropologist. Needless to say, such videos-produced in towns where public electricity is unavailable - are many more times expensive than a saint's photo. In some cases, saints have authorized certain individuals to make what amount to official video recordings of the annual visits and sometimes to take their portraits. Guaranteed such privileges, some of these people-entrepreneurs so to speakhave profited handsomely from the sale and distribution of these religious commodities. ${ }^{25}$ Given how eager people are to add a saint's photo to their collections, many recognize the potential profit to be had from the reproduction and sale of saints' photos. At the annual visits, I have watched as crowds have quickly gathered around those announcing the sale of official and unofficial photos.

All of these religious commodities-photos, videos, printed fabric-can be widely diffused. ${ }^{26}$ Indeed, they circulate with the visitors who pass them on through trade and exchange with others at home and among migrant communities elsewhere in Africa and beyond who might not be able to travel to the provincial towns for the annual visits. I have found such religious commodities-photos of saints prominently displayed in living rooms and videos of the annual visits -in the homes of Malian migrants living in France. More than one Malian in France told me he recognized me from viewing the official videotaped recordings of those annual visits $\mathrm{I}$ attended (and during which I was invariably videotaped). And because of my association with and relatively easy access to the saints, Malians repeatedly ask me to give them or even to sell them photos of the saints they assume I must have.

Such religious commodities have certainly helped to spread the reputations of the saints and their 'fame' (Munn 1986), but also their presumed arc of power. For many, these religious commodities unambiguously index the saint's influence and sanctity. These religious commodities have undoubtedly helped to make the handful of saints

25 See Tambiah 1984 on amulets.

${ }_{26}$ The fabric seems to have been rarely worn, instcad becoming a collector's item that women store away with the intention of passing on to female kin. superstars, not least because most are aware that it is not just anyone whose image can be commercially viable. Many seem truly awed by the video and photographic images of the enormous crowds gathered under the leadership of the respective saints during the annual visits. Some have told me that they have made plans to attend or have actually attended the annual visits after the lasting impression such images have made on them. This has not, however, meant the unproblematic spread of the saints' influence along with the flow of such religious commodities. It is interesting to note that the fabric with one of the saint's images and, by extension, that particular saint became the subject of critique by certain Muslims, perhaps a minority, who have been opposed to such representational art. Such people-we might call them 'reformist' Muslims - see such images as evidence that the saint, or, at the very least, some of his followers are guilty of idolatry or 'association' (Ar., shirk), that is, treating things other than God as a deity; in short, this is un-Islamic behavior. ${ }^{27}$ This is just one feature of a larger Muslim 'reformist' discourse that contests the legitimacy of all supposed living Muslim saints, their alleged powers of intercession, and, by extension, giving gifts to them.

Such criticisms are very serious indeed and may partly explain why some saints have taken steps to restrict the commercialization of their images or what they see as excessive profiteering in the sale of such images. Clearly, the saints do not savor the idea of just anyone profiting financially from the sale of their images. On more than one occasion, I have seen a saint stop someone from taking his photo or videotaping him. Once I watched as a saint instructed a member of his entourage to prevent a young man from videotaping him and the activities at the annual visit. I later learned that the young man was the son of a wealthy migrant without any particular attachment or relationship to the saint, and this man was merely seeking to exploit the commercial possibilities of videotaping the saint. While the saints have sometimes reacted angrily to the unauthorized commercialization of their images or excessive profiteering, they have not been able to control the proliferation and circulation of these commodities, even if they wished.

${ }^{27}$ On so-called reformist Muslms and therr discourses in Mall, see Brenner 1993, Amselle 1985, and Soares 1997a, 1997b. For Niger, see Masquelier 1999. 
Free-floating Sanctifiers and the Serouce Economy

For members of the West African elite-successful merchants, government officials, civil servants, politicians, even heads of state and their kin-visits with Malian saints are, as one might imagine, rather different from visits with ordinary people. The vast resources-economic and political capital- of such people facilitate their interactions and ties with the saints. This is particularly the case for those Malians who seem to have benefited most from some of the changes associated with neoliberalism, particularly liberalization and the opening up of new markets to foreign imports and the expansion of the export sector. These include those merchants, investors, and government officials (such as customs agents) involved as major actors in the trade in imports - foodstuffs, fuel, and consumer items ranging from electronics to automobiles-as well as traders in precious gemstones. In other words, those entrepreneurs who have been able to make the most of some of the recent economic changes. In general, many-perhaps most-of the elites interested in the saints do not participate in the annual large-scale visits. If some of them simply want to avoid the crowds, others prefer that their interactions with a saint remain discreet, even secret. After all, many such people want to visit a saint for help with urgent this-worldly matterswealth, commercial success, political power - that they would hope to keep private. Moreover, they would want to ensure that they have the undivided attention of the saint and his charisma-something very difficult, if not impossible, to achieve during the large-scale visits with thousands of participants.

It is not an exaggeration to say that the world of commodities saturates the interactions between saints and the elite. For some members of this elite, their visits have come to be like holiday tours; they arrive in private or hired cars or by commercial or chartered flights from the capital. Sometimes they send their private cars overland to meet them at the airport at their destination. In certain cases, they lodge in luxury accommodations that have been specially constructed since the late 1980 s for visitors not accustomed to provincial living. Some have even built their own luxury homes for thetr regular visits to the saint's town.

Unlike the overwhelming majority of visitors to the towns, these visitors are usually guaranteed relatively direct access to the saints. Their visits invariably include a private audience with the saint during which they are able to communicate their concerns directly to him. It seems that they gain this much less restricted access because of the lavish nature of their gifts. Although saints and their entourages readily deny the truthfulness of such a statement and note that saints dispense blessings to one and all, those who are the bearers of gifts of great value-new imported cars, expensive wristwatches, and accommodation in luxury hotels during the saint's European tours-never have difficulties in seeing the saint and attaining personal meetings.

In exchange for sumptuous gifts, the saints give blessings to the elites, as they do for the ordinary followers. But the saints also perform much more personalized services for them. ${ }^{28}$ That is, the saints usually employ special prayers so that the elites might obtain what they desire. The saints might also use some of the other Islamic esoteric sciences, including forms of mystical retreat (Ar., khalwea) and Islamic 'divination' (Ar., istikhara) for these high-status visitors (cf. Shaw 2002). It is possible that the saint or a member of his entourage will write special, presumably personalized texts in Arabic (the language of the sacred texts in Islam) for them to wear or to keep as amulets, or even write texts to ingest or with which to wash after effacing with water. These blessings, prayers, and amulets are also religious commodities, and they also seem to possess some of the charisma of the saints (cf. Tambiah 1984). But they are different in a number of ways that make them potentially more powerful than the other commodities like photos and videocassettes. ${ }^{29}$ These religious commodities are not only presumably more personalized, but also always concealed, that is, not publicly displayed. Moreover, the actual contents of such religious commodities will almost always remain mysterious to the recipient, thereby enhancing their power. Finally, most people assume that such powerful religious commodities would almost always be given in exchange for gifts of great value. Thus, the personalized religious commodities are much more highly valued and coveted than those available and affordable to most ordinary people. In exchange for their gifts, elite followers have relatively unfettered access to the saints, their blessings, and more personalized and, therefore, powerful religious commodities. ${ }^{30}$

$-{ }_{-1}^{-}-$

${ }^{28}$ It is important to note that saints dre not known to visit other people, though a member of their entourage might do so on their behalf

${ }_{29}$ Elite followers are also more likely to have personalızed photos of the saints in which they pose with one of the saints. These are prominently displayed in homes and in places of business

${ }^{30}$ This is not unlike Werbner's (1990) discussion of a hierachical gift economy 
At least some of the elites, who do not necessarily have any longrange spiritual--even ideological-commitments to the saints, effectively pay them fees for services. ${ }^{31}$ In fact, certain elite followers are known to solicit more than one saint. That is, after visiting one saint for help with a particular problem, a person might visit another saint for the same, still unresolved problem. It is significant that such a practice is something that is explicitly forbidden in locally understood Islamic religious doctrine, whereby one must not frequent Muslim religious leaders, including saints, indiscriminately. ${ }^{32}$ In their relations with some members of the elite, the saints have thus become what we might call free-floating sanctifiers in a religious economy that is more like a market. Although this might seem to be the language of an outside analyst, I have indeed heard some Malians express such views. They criticize the activities of certain Muslim religious leaders, though generally without naming names, denouncing them as petty traders or merchants who sell their prayers and amulets, sometimes to the highest bidder. While there is general agreement that saints do not have set fees for their services, many point to inflation-rising fees for particular services-as well as inflationary pressures in this service economy. That is, even without set fees, more is often expected in return for the saintly services.

If some Malians suggested to me that the privileged relations between elites and saints would eventually undermine the religious authority of particular saints (cf. Soares 1996b), it is striking that such criticisms generally do not target the notion of saints or sainthood per se. Many people direct their criticisms instead toward those who act as intermediaries with the saints, frequently accusing them not only of hindering access to the saints but also of graft and corruption. This is not unlike the person around a charismatic ruler, described by Weber, "who can take over responsibility for the acts of government, especially for failures and unpopular measures" (Weber $1978,1147)$. Needless to say, that saints themselves remain above criticism is dismaying to certain modernizing actors in Mali, partic-

${ }^{31}$ This is a theme I have developed elsewhere (see Soares 1997b). See Comaroff 1994 (311) and Comaroff and Comaroff 2000 after Wellcr 2000 for a broader discussion of the development of 'fec-for-service' religions.

${ }^{32}$ This is a subject discussed in some detail in written texts associated with the Tijaniyya Suf order where people are instructed to choose a religious leader and not to frequent others. See Abun-Nasr 1965. ularly members of the small, urban secular elite. ${ }^{33}$ For some members of this elite, saints embody all that they find reprehensible about the 'traditional.' For instance, I know many Malian civil servants who condemn in often very moralizing - though always rather hushed-tones what they see as the profligacy of the Muslim saints. ${ }^{34}$

Be this as it may, one can say that for many people in postcolonial Mali, religious authority has been personalized in these provincial saints. Although this notion of personalization draws upon the writings of Weber, it departs significantly from them. According to Weber, when charisma becomes routinized, it is necessarily less 'revolutionary' and less important. In this way of thinking, if charisma becomes hereditary and attached to a particular lineage, it also becomes 'depersonalized' (Weber 1978, 1135ff.). However, what I want to argue is that charisma in this setting has not undergone a process of 'suffocation' in the face of material interests (ibid., 1120). Rather, charisma is a potentiality that manifests itself in the personalized authority of certain religious leaders, who come from certain lineages with hereditary sanctity. Indeed, such figures have been able to re-personalize charisma. The commodity form has been a key element in this process of personalization.

Religious authority has come to be centered on a few individual saints rather than any institutions like the Sufi organizations with which they have historically been associated (cf. Weber 1978, 1135ff.). Indeed, if anything, the institutional basis of the Sufi orders has been shrinking in postcolonial Mali, a situation, which, by almost all reports, does not seem to be the case in neighboring Senegal. ${ }^{35}$ Even in those regions in Mali where the Sufi orders have been important historically, it is increasingly rare for people to be initiated formally into any Sufi order. However, the decline in the organizational importance of the Sufi orders does not mean that notions of hierarchy and charisma, embodied most importantly in the notion of the Muslim saint, are any less important. Nor does this suggest that people have been embracing more 'reformist' ideas about Islam though this is

${ }_{33}$ On urban-based secularists in Mali, see Brenner 1993 and Soares 1997b. if As Miller (1995a) points out, many social scientists that study commodities and consumption use very similar moralizing discourses. See also Milles 1995b.

35 The continuing importance of the Sufi orders in Senegal undoubtedly relates to differences in the colonial experience, particularly French colonial policies towards Muslims, as well as postcolonial state policies. See the references in note 3. 
happening in some cases-or even that some are finding 'secularism' more appealing. To the contrary, with the decline in the organizational importance of the Sufi orders, certain Muslim saints have become known for their individual saintly qualities and their association with wondrous things. It is striking that the saints' rise to prominence has paralleled some of the broader transformations associated with neoliberalism, including the shift to more contractual relations as witnessed elsewhere (see Comaroff and Comaroff 2000).

If many Malians from all sectors of society express disdain for certain kinds of ordinary religious specialists, particularly those minor 'traditional' Muslim religious figures who make a living as diviners or sellers of amulets, these very same people often consider a particular Muslim saint authentic. This is the case even though many admit that one might never know for sure if someone is truly a saint. In any case, the presumed saints attract followers and clients from all sectors of society, from the poorest to the most influential, including African heads of state and government ministers, not all of whom, one should note, are Muslims (see Diallo 1988). Similarly, I know self-professed 'reformist' Muslims involved in one way or another in the neoliberal economy who have traveled themselves to visit the saints, seeking blessings from them or their intercession with God to facilitate business transactions or to ensure financial success.

Although visits with saints have been occurring for centuries in West Africa, such activities have expanded and accelerated, especially in the recent postcolonial period. The French colonial state took particular note of gifts, especially hadaya, given to Muslim religious leaders and often tried to restrict considerable accumulation on their part, not to mention ordinary people's visits with them. ${ }^{36}$ In the late 1930s, a Muslim saint - the father of one of the saints discussed here-received a brand-new imported Ford Mercury as hadaya from a group of his followers who lived in the more prosperous neighboring French colony of Côte d'Ivoire. That this saint had at his disposal means of transport in considerably better shape than that of the local colonial officials was certainly dismaying to certain French administrators. ${ }^{37}$ The saint's African Muslim followers (not to mention his African detractors) could hardly have missed

$-1-$

${ }^{36}$ Th1s also related to the broader French colonial policies towards Muslims (la poltzique musulmane) in this part of West Africa.

${ }^{37}$ Archives Nationales du Mall, Koulouba, unclassified documents, 1937-1939. so obvious a fact. ${ }^{38}$ Unlike the colonial state, the postcolonial Malian state has not restricted the interactions between saints and their followers, nor the exchange, accumulation, and redistribution of resources around them. In fact, the postcolonial state has often facilitated such interactions and accumulation, thercby helping to boost the reputations of certain saints who sometimes attract followers from across the region. It is widely discussed in Mali how the postcolonial state and its agents exempted the saints from paying import duties on those things considered hadaya. If General Moussa Traoré, Mali's second president, lavished gifts upon the saints, it is worth emphasizing that extravagant gifts from officials from the highest levels of the government to the very same saints have continued in the era of multiparty elections in Mali. Modern means of communication and transportation have been important to the activities around the saints. On a much greater scale, people-elite and nonelite-are able to travel relatively easily over greater distances to the towns for the annual visits and at other times of the year and give gifts to the saints. Such gift giving has only intensified in the neoliberal era. I have been present on several occasions when new imported cars have been delivered to the saints, who, like their colonial-era predecessor mentioned above, not only have better and newer vehicles than the local postcolonial administration, but generally a wider selection of cars, including the latest models. In the 1990s, Malian saints received Toyota Landcruisers and pickup trucks--the preferred vehicles for navigating roads that have seriously deteriorated since the colonial era when they were built and maintained through the use of forced labor.

But why the focus on a handful of saints? There is a prevailing notion that there can be only one spiritual head within a particular saintly lineage (cf. Bagayoko 1987). Thus, certain individuals-either the oldest or most 'charismatic'-become a major, if not the sole, locus of gift giving for a particular saintly lineage. In recent times of economic and political uncertainty-structural adjustment, currency devaluation, political upheaval-many ordinary Muslims have turned to the provincial saints who are thought to be close to God. Many of those looking to the saints are urban-dwellers or migrants associated with urban economic activities and market trading. Many such people are struggling to attain wealth and economic success or

${ }^{38}$ It is perhaps no coincidence that the colonial administration eventually accused this saint of subversive inten 
simply to maintain and to reproduce what they have already acquired in an increasingly precarious economy. In many cases, they appeal to the provincial saints when their chances of economic success seem dim. What seems to be new in this era of fast wealth is that many facing bankruptcy will often try to secure loans in order to provide expensive gifts that they otherwise could not afford. It is surprising (at least to me), though apparently not unusual for a saint's retainerwhose own economic success might also be precarious-to inform someone even publicly that an intended gift to a saint is woefully inadequate. One struggling petty merchant I know pleaded with his friends and relatives to loan him the money he needed to purchase a gift of significant value for one of the saints. Others facing ruin in risky trading schemes or those attempting to profit from the sale of cheap imports travel to the saints' towns in a desperate bid to reverse their fortunes. I have also met others involved in the traffic in precious gemstones who do the same. Such ordinary people revere the same Muslim saints as the elites, drawn by a saint whose reputation they very well may have learned about through word of mouth, the mass media, and popular culture. Rumors about saints, wealth, and potential wealth circulate widely, with many of these rumors focused on the wonders of defying the uncertainties of the market. I cannot recall how often I have heard ordinary Malians discuss the fantastic wealth of the country's most prominent merchants and the newfound and sometimes instant wealth of Malians of modest means as a direct result of their association with the saints and their presumed services. With such attention on the saints' wonders and gift giving focused so closely upon them, people effectively push other members of the saintly lineages out of the religious economy, permanently or at least until a period of succession in the event that the saintly character of a particular lineage has not been exhausted.

It is significant that the saints usually remain in their provincial towns. With very few exceptions, they do not visit others. They travel rarely to the large towns in Mali, and when they do visit, say, the capital, they never stay very long. ${ }^{39}$ While cities and large towns are known as places where decadence and impiety reign (the exact opposite of what saints are thought to embody [Werbner 1998]), more

${ }^{39}$ Sants might vist the capital when they are in transit, for example, to catch a flight to perform the Haj or to visit followers in Europe or possibly to seek medical attention in one of the capital's private clinics. important, perhaps, is the fact that the religious economy in such large urban centers is invariably more complex and diverse. In short, competition is much more intensive there. All of this is without mentioning the saints' potential critics - urban-based secularists and 'reformist' Muslims who contest the legitimacy of saints.

\section{Conclusion}

An expanded network of persons--elite and nonelite-is in patronage relations with the saints and their lineages, transferring commodities and money to them. In this era of marked economic decline, the scale of the annual visits has gone up, and there have been huge infusions of capital, construction of expensive homes, and the acquisition of luxury items by the saints. The great wealth of the saints has allowed them to maintain enormous households in which the women-wives and daughters--live in seclusion and in great comfort. Although it should be clear by now that saints are not necessarily expected to lead austere lives, the saints do, however, provide alms-never enough, some critics note-for the many poor individuals who gather around them and reward their faithful followers. Through accumulation, the individual saints have been able to exhibit the signs of wealth, very large families, and support of followers, the 'gifts of God' that index their sanctity and seeming immunity from the incredible political and economic uncertainty most people facein short, their 'power.' The saints seem to have been immune to the 1991 overthrow of a seemingly omnipotent president with whom they all had ties. Moreover, as many Malians point out, they seem not to have suffered financially (and may even have profited) when the currency was devalued by half at the beginning of 1994. Last but not least, the saints demonstrate the unambiguous capacity for successful-indeed even hypersuccessful-social reproduction in this era of neoliberal reforms, decline, and crisis.

The elite followers have been key actors, facilitating the displays of wealth that have helped to boost the reputations of the saints, reinforcing and extending their religious power and authority. But nonelite followers have been no less important here, because of their number, the volume of their gifts, and the new religious commodities they help to diffuse. Malian saints in postcolonial Mali have the reputation of being more pious than ordinary people, as being moral 
exemplars, and, in this way, somewhat like Weberian puritans; however, they are not ascetic, even if they do live far from major urban and economic centers. In Mali, commodification has been perhaps one of the most important factors in the personalization of religious authority in certain Muslim saints, ensuring that the saints embody much that is elusive-sainthood, wealth, fame--though no less desirable for many if not most ordinary people in the age of neoliberalism and market triumphalism. As Weber suggested long ago, the relationship of religious practices and the market is very complex indeed. In this case too, it would be tendentious to claim that neoliberalism has reduced religion to the logic of the market. After all, certain Muslim saints in Mali seem to have even more authority, not least for their seeming capacity to defy the vagaries of the market and to infuse that very market with its allure.

\section{Acknowledgments}

Field rescarch in Mali in 1992, 1993-94, and 1998-99 was supported by FulbrightHays, USIA/Fulbright and the West African Research Association, the WennerGren Foundation, Northwestern University, and a National Science Foundation-NATO Postdoctoral Fellowship. The NIMH Program on Culture and Mental Health Behavor at the University of Chicago Committee on Human Development provided funds in the form of a postdoctoral fellowship I am grateful to Jean-Loup Amselle, Ralph Austen, Jean Comaroff, Constant Hamès, Danièle Hervieu-Lécer, Adeline Masquelier, Hudita Mustafa, Armando Salvatore, Rudiger Seesemann, Rosalind Shaw, and Pnina Werbner for ther comments and surgestons. As always, I am most indebted to the many people in West Africa who have helped me with this material and its analysis.

\section{REFERENGES}

Abun-Nasr, Jamil M. 1965. The Tyanyyya A Sufi order in the modern woorld London Oxford University Press

Ali, A., trans. 1984 Al-Qur'an. Princeton, NJ: Princeton University Press

Amselle, Jean-Loup. 1985 'Le wahabisme à Bamako (1945-1885).' Canadran Journal of African Studies 19:345-357.

Asad, Talal. 1986. The udea of an anthropology of Islam Occasional Papers Series. Washington, DC: Georgetown University Center for Contemporary Arab Studees. Bagayoko, Shaka. 1987. 'L'Etat au Mali: Représentation, autonomie, et mode de fonctionnement' In L'Etat contemporain en Afrque, edited by Emmanuel Terray Parrs L'Harmattan

Beidelman, T. O 1971 'Nuer prests and prophets' In The translation of culture Essays to E. E. Evans-Prtchard, edited by T. O Beidelman London. Tavistock. Bourdieu, Pierre. 1977. Outline of a theory of practice, translated by Richard Nice. Cambridge: Cambridge University Press
Bowen, John R. 1992. 'On scriptural essentialısm and ritual variation: Muslim sacrifice in Sumatra and Morocco.' Amencan Ethnologst 19:656-671.

Brenner, Louis. 1993. 'Constructing Muslim identities in Malı' In Muslm udentzly and sactal change in sub-Saharan Afruca, edited by Louis Brenner. Bloomington: Indiana University Press.

Chodkiewicz, Michel. 1986 Le Sceau des sannts: Prophétre et sannteté dans la doctrne d'Ibn Arab. Paris: Gallimard.

Colin, G. S. 1971. 'Hiba.' In Encyclopaedia of Islam, 2nd ed. Lerden: Brill. Comaroff, Jean. 1994. 'Epilogue. Defying disenchantment: Reffections on ritual, power, and history.' In Aszan vaszons of authonty, edited by Charles F. Keyes, Laurel Kendall, and Helen Hardacre. 1999 'Occult economies and the violence Comaroff, Jean, and John L. Ciomarof. 19y9. 'Occult econs.' Amemcon Ethologst of abstraction: Notes from the South African postcolony.' Amencan Ethnologist
26(2):279-303.

- 2000. 'Millennial capitalism: First thoughts on a second commg.' Public Cullure 12(2):291-343.

Copans, Jean. 1988. Les marabouts de l'arachude. Paris. L'Harmattan.

Coulon, Christian. 1981. Le marabout et le pronce. Pars: Pedone.

Coulon, Christian. 1988. Les musulmans et le pouvorr en Afrque norre, 2nd ed. Paris: Karthala.

Grapanzano, Vincent 1973. The Hamadsha. Berkeley: University of California Press Cruise O'Brien, Donal B. 1971. The Mourdes of Senegal. Oxford: Clarendon Press. Cruse 1975 , Samts and poltzczans. Cambridge: Cambridge University Press.

Cruise O'Brien, Donal B., and Christian Coulon, eds. 1988 Chansma and brotherhood in Afrcan Islam Oxford. Clarendon Press.

Dannerlein Bettma 2001 'Legitimate bounds and bound legtimacy: The act of

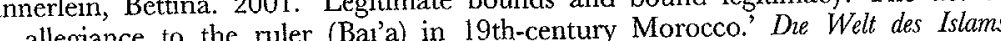
43(3): $1-23$.

Denny, Frederick M. 1988. " "God's friends": The sanctity of persons in Islam.' In Samthood edited by Richard Keeckhefer and George D. Bond. Berkeley: University of California Press.

Diallo, Tidiane 1988. 'Pouvoir et marabouts en Afrique de l'Ouest.' Islam et soczétés au sud du Sahara 2:7-10.

Dieterlen, Germaine. 1951. Essat sur la relagon Bambara. Paris: Presses Universitarres

de France.
Dumont, Louis 1980. Homo herarchacus: The caste system and its implications, complete English ed., rev. Chicago: University of Chicago Press.

Eickelman, Dale F. 1976. Moroccan Islam. Austin: University of Texas Press.

Eickelman, Dale 'Inside the Islamic reformation.' Wilson Quartely (Winter):80-89.

Eickelman, Dale F., and James Psscatori. 1996. Mushm polttcs. Princeton, NJ: Princeton University Press.

El Bokhari. 1964. L'Authentrque tradtton musulmane, translated by G. H. Bousquet. Paris: Fasquelle

Fing Katherine. 1983 "The politics of Sufism: Redefining the saints of Pakistan. foumal of Astan Studies 42(2):251-68.

Geertz, Clifford 1968. Islam observed. Chicago: University of Chicago Press.

Gellner, Ernest 1969 Sants of the atlas Chicago: University of Chicago Press.

1981. Mushm soczety. Cambridge. Cambridge University Press

1992 Postmodernism, reason, and relionon. New York: Routledge

1994. 'Foreword.' In Islam, globalization and postmodernily, edited by Akbar S Ahmed and Hastings Donnan New York Routledge

Gilsenan, Michael. 1973. Sant and Sufi in modern Egypt. Oxford Clarendon Press. Gilsenan, 1982 Recognzzing Islam New York' Pantheon

Gracber, David. 1996 'Beads and money Notes toward a theory of wealth and power.' Amercan Ethnologist 23(1):4-24. 
Hamès, Constant. 1979. 'L'évolution des émirats maures sous l'effet du capitalisme marchand européen.' In Pastoral production and society/Production pastorale et société, edited by L'Equipe écologie et anthropologie des sociétés pastorales. Cambridge and Paris: Cambridge University Press and Editions de la Maison des Science de l'Homme.

Hammoudi, Abdellah. 1997. Master and disciple: The cultural foundations of Moroccan authoritarianism. Chicago: University of Chicago Press.

Harrison, Christopher. 1988. France and Islam in West Africa, 1860-1960. Cambridge: Cambridge University Press.

Hoffman, Valerie J. 1995. Sufwsm, mystics, and saints in modern Egypt. Columbia: University of South Carolina Press.

Kazimirski, A. de B. 1860. Diciionnaire arabe-frangais. 2 vols. Paris: Maisonneuve.

Lambek, Michael. 1993. Knoweledge and practice in Mayotte: Local discourses of Islam, sorcery, and spirit possession. Toronto: University of Toronto Press.

Launay, Robert. 1992. Beyond the stream: Islam and sociely in a West African town. Berkeley: University of California Press.

Launay, Robert, and Benjamin F. Soares. 1999. "The formation of an "Islamic sphere" in French colonial West Africa.' Economy and Society 28:497-519.

Marty, Martin E., and R. Scott Appleby, eds. 1991. Fundamentalisms observed. Chicago: University of Chicago Press.

Masquelier, Adeline. 1999. 'Debating Muslims, disputed practices: Struggles for the realization of an alternative moral order in Niger.' In Civil society and the political imagination in Afrca, edited by John L. Comaroff and Jean Comaroff. Chicago: University of Chicag, edited

McLaughlin, Fiona. 1997. 'Islam and popular music in Senegal.' Africa 67:560-581.

Messick, Brinkley. 1993. The calligraphic state: Textual domination and history in a Mustim society. Berkeley: University of California Press.

Miller, Daniel. 1995a. 'Consumption and commodities.' Annual Review of Anthropology 24:141-161.

. 1995b. 'Introduction: Anthropology, modernity and consumption.' In Worlds apart, edited by Daniel Miller. New York: Routledge.

Munn, Nancy. 1986. The fame of Gawa. Cambridge: Cambridge University Press.

Nicholson, Ralph A. 1921. Studies in Islamic mysticism. Cambridge: Cambridge University Press.

Perry, Donna. 1998. 'The patriarchs are crying: Discourses of authority and social change in rural Senegal.' Ph.D. dissertation, Yale University.

al-Qayrawani, 'Abdullah b. Abi Zayd. 1975. Al-Risala. 6th ed., edited and translated by L. Bercher. Algiers: Editions populaires de l'armée.

Robinson, David, and Jean-Louis Triaud, eds. 1997. Le temps des marabouts. Paris: Karthala.

Ruxton, F. H. 1916. Maliki law. London: Luzac.

Sahlins, Marshall. 1992. 'The political economy of grandeur in Hawai'i from 1820 to 1830.' In Culture through time, edited by Emiko Ohnuki-Tierney. Stanford: Stanford University Press.

Seesemann, Rüdiger. 1993. Ahmadu Bamba und die Entstehung der Muridiyya. Berlin: Klaus Schwarz.

Shaw, Rosalind. 2002. Memories of the slave trade: Ritual and the historical tmagnation in Sierra Leone. Chicago: University of Chicago Press.

Soares, Benjamin F. 1996a. 'A contemporary Malian shaykh.' Islam et societés au sud du Sahara 10:145-153

- 1996b. 'The prayer economy in a Malian town.' Cahters d'Etudes afncaines 36:739-753

- 1997a. 'The Fulbe Shaykh and the Bambara "Pagans."' In Peuls et Mandingues: Dialectique des constructions identitaires, edited by Mirjam de Bruijn and Han van Dijk. Paris: Karthala.
- 1997b. "The spiritual economy of Nioro du Sahel: Islamic discourses and practices in a Malian religious center.' Ph.D. dissertation, Northwestern University. - 2000. 'Notes on the anthropological study of Islam and Muslim societie in Africa.' Culture and Religion 1(2):277-285.

- n.d. ' 'Les sciences esotériques islamiques et le traffic d'amulettes au Mali.' In Magie et écriture islamique edited by Constant Hamès. Paris. Forthcoming.

In 2 'I lam and public piety in Mali' In Public Islam and the common

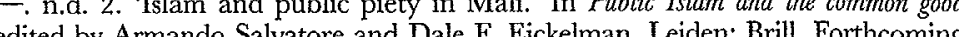
edited by Armando Salvatore and Dale F. "Eickelman. Leiden: Brill. Forthcoming.
. The shaykh as the locus of divine selfdisclosure.' Sudanic Africa: A foumal of Historical Sources 7:97-112. disclosure.' Sudanic Africa: A Foumal of Historical Sources 7:97-112.
arrett, Gregory. 1995. 'The political economy of religious commodities in Cairo.' Starrett, Gregory. 1995. 'The political
American Anthropologist 97:51-68. American Anthropologist 97:51-68.
Tambiah, Stanley J. 1984. The Buddhist saints of the forests and the cult of the amulets. Cambridge: Cambridge University Press.

Triaud, Jean-Louis.1986. 'Le theme confrerique en Afrique de l'ouest: Essai historique et bibliographique.' In Les Ordres mystiques dans l'Islam: Cheminements el situation actuelle, edited by Alexandre Popovic and Gilles Veinstein. Paris: Editions de l'EHESS.

Turner, Bryan S. 1974. Weber and Islam. London: Routledge \& Kegan Paul.

Turner Victor W. 1973. 'The center out there: Pilgrim's goal.' History of Religion 12:191-230.

Villalón, Leonardo A 1995. Islamic society and state poxver in Senegal: Discoples and citizens in Fatick. Cambridge: Cambridge University Press.

Weber, Max. 1978. Economy and society. 2 vols. Berkeley: University of California Press.

Weller, Robert P. 2000. 'Living at the edge: Religion, capitalism, and the end of the nation-state in Taiwan.' Public Culture 12(2):477-498.

Wensinck, A. J. 1927. A handbook of early Muhammadan tradition. Leiden: Brill.

Werbner, Pnina. 1990. 'Economic rationality and hierarchical gift economies: Valuc and ranking among British Pakistanis.' Man (n.s.)25:266-285.

- 1998. 'Langar: Pilgrimage, sacred exchange and perpetual sacrifice in Sufi saint's lodge.' In Embodying charisma, edited by Pnina Werbner and Helen Basu. New York: Routledge.

Werbner, Pnina, and Helen Basu, eds. 1998. Embodying charisma: Modernity, localit) and the performance of emotion in Suff cults. New York: Routledge.

Willis, John R. 1976. 'The Western Sudan from the Moroccan invasion (1591) to the death of al-Mukhtar al-Kunti (1811)' In History of West Africa, edited by the death of al-Mulhtar al-Kunt (1811)' J 2 J is there a Muslim society? Ernest Gellner's sociology of Islam.' Economy and Society 24(2):151-188. 